\author{
ISLĀMIYYĀT 42(1) 2020: 3 - 14 \\ (https://doi.org/10.17576/islamiyyat-2020-4201-01)
}

\title{
Kesan Sikap, Faktor Halangan dan Manfaat Tanggapan Pekebun Kecil Sawit Persendirian Kepada Niat Menggunakan Mikro Kredit Islam
}

\author{
Effects of Behaviour, Obstacle Factor, and Benefit of Smallholder Palm Oil Farmers Perception \\ on The Intention to Use Islamic Micro Credit
}

\author{
Muhammad Hakimi Mohd. Shafiai \\ Syahrul AnUar Ali \\ SALMy EdAWATI YAACOB
}

\begin{abstract}
ABSTRAK
Kekurangan modal kewangan merupakan masalah utama yang dihadapi oleh Pekebun Kecil Sawit Persendirian (PKSP) dalam meningkatkan produktiviti kelapa sawit. Walaupun terdapat 6 buah institusi perbankan Islam menyediakan mikro kredit kepada golongan petani, tetapi produk ini tidak mendapat sambutan dari golongan petani terutamanya PKSP. Bagi merungkai faktor yang menyebabkan PKSP kurang berminat mengambil mikro kredit dari perbankan Islam, kertas ini menggunakan konsep niat Al-Ghazali untuk mencapai dua objektif yang dikaji. Objektif pertama, menganalisis kesan sikap terhadap mikro kredit Islam, faktor halangan dan manfaat tanggapan kepada niat menggunakan mikro kredit Islam. Objektif kedua, menganalisis kesan faktor halangan dan manfaat tanggapan kepada sikap terhadap mikro kredit Islam. Bagi memahami fenomena ini, kajian telah dilaksanakan di daerah Hilir Perak, Malaysia yang melibatkan seramai 362 orang PKSP. Data kajian yang diperolehi melalui soal selidik dianalisis menggunakan Structural Equation Modelling (SEM). Kertas ini mendapati faktor halangan dan sikap terhadap mikro kredit Islam signifikan mempengaruh niat menggunakan mikro kredit Islam, manakala manfaat tanggapan didapati tidak signifikan mempengaruhi niat. Kertas ini turut mendapati, pembentukkan sikap terhadap mikro kredit Islam hanya dipengaruhi oleh manfaat tanggapan. Kertas ini merumuskan bahawa, PKSP kurang berminat mengambil mikro kredit Islam untuk tujuan pertanian kerana ciri-ciri produk mikro kredit yang ditawarkan oleh institusi perbankan Islam kurang menarik dan tidak kompetatif. Sehubungan dengan itu, kertas ini mencadangkan institusi perbankan Islam perlu menambah baik ciri-ciri produk mikro kredit serta menjalinkan hubungan rakan strategi dengan pemain industri yang lain bagi mengurangkan risiko dan seterusnya menawarkan produk mikro kredit yang kompetatif di pasaran.
\end{abstract}

Kata kunci: Mikro kredit Islam; al-Ghazali; B40; gelagat petani; modal kewangan.

\section{ABSTRACT}

The lack of financial capital is the main problem faced by the smallholder palm oil farmers (Pekebun Kecil Sawit Persendirian, PKSP) in order to increase the productivity of palm oil. Although there are six Islamic banking institutions that provide micro credit for the farmers, this product however does not get a good response from the farmers especially among the PKSP. In order to dismantle the factors of the PKSP having less interest to take up the micro credit from Islamic banking institutions, this paper employed Al-Ghazali's concept of intention to achieve two research objectives. In regards to the first objective, this research analyses the effects of behaviour towards Islamic micro credit, obstacle factor, and the benefit of perception on the intention to use Islamic micro credit. In regards to the second objective, this research analyses the effects of obstacle factor and the benefit of perception on the behaviour towards Islamic micro credit. This research was conducted at the district of Hilir Perak, Malaysia involving 362 PKSP to understand this phenomenon. The research data were obtained from a questionnaire which was analysed using structural equation modelling (SEM). It was found that the obstacle factor and behaviour towards Islamic micro credit influence the intention to use Islamic micro credit, while the benefit of perception was found to be insignificant in influencing the intention. This paper also found that the behaviour towards Islamic micro credit is developed and influenced by the benefit of perception. It can be concluded that the PKSP are less interested to take up the Islamic micro credit for agricultural purpose because the features of micro credit product offered by the Islamic banking institutions are less attractive and not competitive. In this case, this paper recommended the Islamic banking institutions to improvise their micro credit product offerings and develop strategic relationship with other industrial players to reduce business risk and eventually offer a competitive micro credit product in the market.

Keywords: Islamic micro credit; al-Ghazali; B40; farmers' behaviour; financial capital 


\section{PENGENALAN}

Di Malaysia, kerajaan memperkenalkan sistem kewangan Islam untuk membantu rakyat bebas dari transaksi kewangan berasaskan riba'. Sehubungan itu, sistem perbankan Islam menyediakan pelbagai produk kewangan untuk memenuhi keperluan penduduk di bandar dan luar bandar. Walau bagaimanapun, penduduk luar bandar di negara ini masih sukar mendapatkan pinjaman sama ada dari perbankan Islam mahupun konvensional. Hal ini terjadi kerana masyarakat luar bandar berpendapatan rendah dan sukar memenuhi syarat-syarat yang ditetapkan oleh pihak bank. Berdasarkan laporan statistik, sebanyak 44\% penduduk luar bandar menghadapi masalah modal kewangan untuk mengembangkan perniagaan dan juga meningkatkan pengeluaran pertanian (Kementerian Kemajuan Luar Bandar dan Wilayah 2010). Sehubungan itu, Kementerian Kemajuan Luar Bandar dan Wilayah (KKLBW) telah memperkenalkan Pelan Induk Pembangunan Luar Bandar (PIPLB) bagi membantu menambahbaik capaian kemudahan kredit oleh penduduk luar bandar. Melalui PIPLB, agensi pelaksana yang terlibat ialah Kementerian Kewangan, KKLBW, Kementerian Pertanian dan Asas Tani, PUNB, Tabung Ekonomi Kumpulan Usahawan Niaga (TEKUN), Amanah Ikhtiar
Malaysia (AIM) dan institusi perbankan. Usaha menambahbaik saluran kemudahan kredit ini melibatkan 2 fasa, fasa pertama bermula 2011 hingga 2015 dan fasa kedua bermula 2016 hingga 2020.

Di samping itu, "Model Baru Ekonomi (MBE) Malaysia" turut mencadangkan institusi perbankan menawarkan pinjaman tanpa cagaran serta membangunkan mekanisme tertentu bagi memenuhi keperluan kewangan perusahaan kecil di bandar dan luar bandar (Majlis Penasihat Ekonomi Negara 2010). Bertitik tolak dari saranan MBE, BNM telah menggariskan langkah-langkah yang perlu dilaksanakan dalam Pelan Sektor Kewangan 2011 - 2020 (Financial Sector Blueprint 2011-2020) (Bank Negara Malaysia 2011). BNM menggalakkan institusi perbankan menawarkan mikro kredit kepada penduduk bandar dan luar bandar dengan menambah baik ciri-ciri produk sedia ada supaya dapat dimanfaatkan oleh kumpulan sasaran. Galakan BNM telah mendapat sambutan daripada institusi perbankan. Terdapat 10 institusi perbankan yang menawarkan pinjaman mikro kredit kepada usahawan dalam pelbagai sektor termasuklah sektor pertanian (Ab Aziz 2011). Daripada jumlah tersebut, sebanyak 6 institusi perbankan menawarkan mikro kredit kepada golongan petani secara patuh syariah (BNM 2016).

JADUAL 1. Institusi perbankan Islam menawarkan mikro kredit patuh Syariah untuk sektor pertanian

\begin{tabular}{cc}
\hline Institusi Perbankan Islam & Tujuan \\
\hline Agrobank & Modal kerja \& pembelian aset tetap \\
Alliance Islamic Bank & Modal kerja \& pembelian aset tetap \\
CIMB Islamic Bank & Modal kerja \& pembelian aset tetap \\
Bank Muamalat & Modal kerja \& pembelian aset tetap \\
Bank Rakyat & Modal kerja \& pembelian aset tetap \\
Maybank Islamic & Modal kerja \& pembelian aset tetap \\
\hline
\end{tabular}

Sebahagian penduduk luar bandar telah menerima impak positif apabila institusi perbankan Islam memperkasa saluran kemudahan mikro kreditn. Namun begitu, Pekebun Kecil Sawit Persendirian (PKSP) tidak berminat untuk melanggan mikro kredit dari institusi perbankan Islam. Di Malaysia, terdapat seramai 221,950 orang PKSP (Perlesenan MPOB 2016), majoritinya tergolong dalam kumpulan berpendapatan rendah (B40) kerana pendapatan bulanan mereka kurang daripada RM 3,860.00 (Siwar et al. 2019). Oleh kerana PKSP berpendapatan rendah, mereka tidak mampu mengurus ladang dengan cekap kerana dibatasi oleh faktor modal kewangan. Hal ini dapat dilihat apabila produktiviti buah tandan segar (BTS) di ladang PKSP lebih rendah berbanding produktiviti BTS di ladang yang diusahakan oleh syarikat perladangan (Cramb \& Sujang 2013; PEMANDU 2010). Usaha meningkatkan akses kemudahan kredit yang dilakukan oleh kerajaan, BNM dan institusi perbankan sepatutnya dapat meningkatkan pendapatan dan melonjakkan produktiviti BTS ke paras 22 tan/hektar/tahun (PEMANDU 2010). Namun, produktiviti BTS dan pendapatan PKSP pada tahun 2015 masih rendah setelah tamat fasa pertama PIPLB. Pada tahun 
2015, produktiviti BTS PKSP hanyalah 17.33 tan/ hektar/tahun dengan purata pendapatan bulanan RM1,177.14 (Kementerian Perusahaan Perladangan dan Komoditi 2016). Isu sukar mendapatkan pinjaman masih lagi dibangkitkan oleh PKSP kerana mereka memerlukan pinjaman untuk membeli bahan input terutamanya baja. Oleh kerana PKSP sukar mendapatkan pinjaman mikro kredit, ramai dalam kalangan mereka mengamalkan pembajaan secara bermusim iaitu apabila harga BTS tinggi dan bergantung kepada wang simpanan sebagai modal kerja (Martin et al. 2015; Ramli 2013).

Terdapat banyak kajian yang mendapati PKSP menghadapi masalah modal kewangan dan memerlukan kemudahan kredit (Ayat K et al. 2008; Claudine \& Reza 2012; Cramb \& Sujang 2013; Martin et al. 2015; Nkongho et al. 2014; Ramli 2013). Isu modal kewangan tidak mencukupi dalam kalangan PKSP memberi impak besar kepada produktiviti BTS negara (Belcher et al. 2004; Martin et al. 2015). Buktinya, walaupun PKSP menguasai $41 \%$ daripada keluasan ladang kelapa sawit di Malaysia, mereka hanya menyumbang sebanyak $10 \%$ daripada produktiviti pengeluaran minyak sawit negara (Chin et al. 2016). Menurut Azman et al. (2003) pada tahun 2000 sebanyak 14\% PKSP di Johor langsung tidak membaja di ladang kelapa sawit mereka kerana tiada modal kewangan. Begitu juga Martin et al. (2015) mendapati PKSP di Sabah hanya membaja dalam kuantiti yang terlalu sedikit berbanding estet. Berpandukan dapatan kajian di atas, dapatlah difahami bahawa masalah kekurangan modal kewangan dalam kalangan PKSP telah lama berlaku dan masalah ini belum menemui jalan penyelesaian. Justeru kajian ini cuba memahami kepada faktor psikologi yang mempengaruhi keputusan PKSP untuk melanggan mikro kredit yang disediakan oleh perbankan Islam dari perspektif Al-Ghazali. Berpandukan konsep niat yang diperkenalkan oleh (Al-Ghazali, 1988), tingakhlaku individu diterjemahkan dari niat, manakala niat pula sangat bergantung kepada tahap kekuatan kemahuan (sikap) individu. Hal ini bererti, apabila PKSP mempunyai kemahuan (sikap) yang kuat terhadap pinjaman, maka niat PKSP untuk melanggan mikro kredit menjadi bertambah kuat. Seterusnya, niat ini akan diterjemahkan kepada gelagat iaitu PKSP melanggan mikro kredit. AlGhazali (1988) turut menjelaskan faktor lain seperti sangkaan dan halangan turut sama mendorong kemahuan serta niat individu untuk bertindak balas. Salah satu sangkaan yang pasti dipertimbangan oleh PKSP adalah manfaat yang dijangka diterima. Dengan melanggan mikro kredit, secara langsung produktiviti BTS dan pendapatan PKSP turut bertambah. Sangkaan manfaat (manfaat tanggapan) turut memberi kesan kepada kemahuan dan niat PKSP terhadap pinjaman mikro kredit. Manakala faktor halangan pula bererti sekatan yang dikenakan oleh institusi perbankan Islam seperti terma dan syarat turut memberi kesan kepada pembentukan kemahuan, malah ia juga memberi kesan langsung kepada niat PKSP untuk mengambil mikro kredit.

Justeru, kajian ini cuba untuk memahami faktor psikologi yang menyumbang kepada niat dan sikap PKSP untuk melanggan mikro kredit yang disediakan di Perbankan Islam. Tumpuan diberikan kepada institusi perbankan islam kerana majoriti petani beragama Islam dan mahukan pinjaman bebas dari unsur riba' (Muhammad Hakimi \& Muhammad Rizki 2015).

\section{KONSEP NIAT AL-GHAZALI}

Melanggan mikro kredit bukanlan tindakan spontan, bahkan ia merupakan tindakan yang dirancang. Oleh kerana melanggan mikro kredit merupakan tindakan yang dirancang, maka ia berkait rapat dengan faktor dalaman iaitu niat. Al-Ghazali (1988) mentakrif niat sebagai satu keadaan atau sifat bagi hati yang dikelilinggi oleh dua perkara iaitu ilmu pengetahuan dan gelagat. Secara umumnya, Al-Ghazali menyatakan niat merupakan faktor dalam diri yang mendorong individu untuk bergelagat. Dengan kata lain, ianya merujuk kepada faktor penolak dari dalam diri individu, dalam dunia moden hari ini ianya dikenali sebagai faktor motivasi. Dalam konteks kajian ini, niat merupakan keazaman yang ada dalam diri individu untuk bergelagat tertentu. Ini bertepatan dengan ayat Al-Quran yang bermaksud:

Maka dengan sebab rahmat (yang melimpah-limpah) dari Allah (kepadamu wahai Muhammad), engkau telah bersikap lemahlembut kepada mereka (sahabat-sahabat dan pengikutmu), dan kalaulah engkau bersikap kasar lagi keras hati, tentulah mereka lari dari kelilingmu. Oleh itu maafkanlah mereka (mengenai kesalahan yang mereka lakukan terhadapmu), dan pohonkanlah ampun bagi mereka, dan juga bermesyuaratlah dengan mereka dalam urusan (peperangan dan soal-soal keduniaan) itu. Kemudian apabila engkau telah berazam (sesudah bermesyuarat, untuk membuat sesuatu) maka bertawakallah kepada Allah, sesungguhnya Allah mengasihi orang-orang yang bertwakkal kepada-Nya.

(Al-Quran; al-'Imran: 159) 
Di samping itu, peranan niat sangat besar dalam Islam kerana ia akan mencorak atau menentukan gelagat yang bakal dikerjakan. Hal ini bertepatan seperti mana hadis Rasulullah S.A.W yang bermaksud:

Amal perbuatan (gelagat) pasti disertai dengan niat, dan setiap orang akan mendapat balasan sesuai dengan niatnya. Siapa yang hijrah semata-mata kerana Allah dan Rasul-Nya maka hijrahnya kepada Allah dan Rasul-Nya; siapa yang hijrah kerana dunia yang akan dia dapatkan, atau hijrah kerana seorang perempuan yang akan dia nikahi, maka hijrahnya sesuai dengan tujuannya.

(Al-Bukhari 1993; Muslim 1984)

Isu niat dapat difahami dari sudut pandang Barat dan Islam. Di barat, Teori Gelagat Terancang (TGT) telah diperkenalkan untuk memahami niat dan gelagat manusia, teori ini telah digunakan secara meluas di seluruh dunia. Teori ini bukan sahaja digunakan untuk memahami keperluan kehidupan, bahkan ianya turut digunakan untuk memahami perkara yang berkait rapat dengan kehidupan seorang muslim. Misalnya, TGT telah digunakan untuk memahami niat gelagat muslim dalam menggunakan sistem perbankan Islam (Han et al. 2017; Zinser 2018), menderma wang (Kashif \& De Run 2015), produk halal kosmetik (Haque et al. 2018), makanan halal (Soon \& Wallace 2017), takaful (Maizaitulaidawati \& Asmak 2016) dan lainlain. Malangnya, belum terdapat kajian empirikal yang menggunakan konsep/teori dari sarjana muslim seperti Al-Ghazali untuk memahami faktor yang mempengaruhi niat gelagat muslim. Secara falsafahnya, terdapat perbezaan antara konsep niat menurut TGT dengan Al-Ghazali. Ini kerana TGT menekankan kepada keupayaan untuk bergelagat semata-mata bagi memenuhi kehendak dan keperluan manusia di dunia. Sebaliknya, konsep niat yang diperkenalkan oleh Al-Ghazali menekankan kepada konsep al-falah iaitu untuk memenuhi kehendak dan keperluan di dunia, pada masa yang sama untuk mencapai kebahagiaan hakiki di akhirat.

Terdapat keperluan untuk memahami isu melanggan mikro kredit dari sudut pandang Islam kerana majoriti PKSP di Malaysia beragama Islam. Melanggan mikro kredit bukan sahaja untuk meningkatkan pengeluaran BTS sematamata, malah ianya dapat mendekatkan diri kepada Allah seperti mengeluarkan lebih banyak zakat, sedekah, dan memberi nafkah yang halal kepada keluarga. Oleh itu, niat yang ikhlas diperlukan untuk mencapai keredaan Allah. Al-Ghazali telah membahagikan taraf niat kepada dua kategori iaitu; i) rendah - niat beramal kerana takut neraka atau mengharapkan syurga, dan ii) tinggi - niat beramal kerana memuliakan Allah. Walaupun niat beramal kerana takut neraka atau mengharapkan syurga merupakan taraf niat paling rendah, namun ianya masih diterima Allah dan dikira mencari keredaan Allah seperti di nukil dalam kitab Ihya' Ulumiddin di bawah tajuk al-niyyah wa al-ikhlas wa alSiqd (Al-Ghazali, 1988). Manakala Al-Qardhawi (2004) pula menjelaskan bahawa untuk mendapat keredaan Allah, sesuatu perbuatan perlu memenuhi dua kriteria iaitu niat yang ikhlas dan perbuatan sesuai dengan sunnah. Sehubungan dengan itu, PKSP muslim wajib menggunakan produk pinjaman patuh syariah apabila mereka memerlukannya. Dari perspektif Al-Ghazali, pengetahuan akan memandu seseorang untuk membuat penilaian sama ada bermanfaat atau berisiko. Justeru, PKSP perlu terlebih dahulu mengetahui wujudnya produk mikro kredit di institusi perbankan Islam sebelum mereka menilai manfaat yang bakal diterima mereka. AlGhazali turut menjelaskan bahawa niat tercetus daripada dorongan pembangkit iaitu kemahuan/ sikap. Ini telah dinukilkan oleh Al-Ghazali seperti berikut (Al-Ghazali 1994):

Anggota tidaklah mampu bergerak (gelagat) tanpa daya, dan daya menunggu dorongan pembangkit (sikap), dan pembangkit menunggu isyarat ilmu dan pengetahuan atau sangkaan dan iktikad (penilaian terhadap manfaat, risiko dan halangan). Dan itikat ini harus lebih dahulu kuat di dalam diri manusia bahawa sesuatu hal tertentu dirasai sudah sesuai untuknya. Bila pengetahuan manusia telah memastikan sesuainya sesuatu untuk dirinya dan harus bertindak (penilaian terhadap manfaat), dan tidak ada pula dorongan lain yang menghambat (halangan) maka timbullah kemahuan (sikap) dan terjadilah kecenderungan hati (niat). Apabila kemahuan telah timbul, maka bangkitlah daya untuk menggerakkan anggota (gelagat). Daya/kemampuan meladani kemahuan (sikap), kemahuan (sikap) mengikuti penetapan yang diberikan oleh pengetahuan dan itikat. Maka "NIAT" adalah situasi kejiwaan yang berada ditengah tadi, iaitu tergeraknya hati (niat) menuruti penetapan kemahuan (sikap) dan kecenderungan ke arah yang sesuai dengan tujuan baik sekarang (gelagat) mahupun yang akan datang (gelagat).

Walaupun petikan di atas hanya menisbahkan kepada gelagat (anggota tidaklah mampu bergerak), secara tersiratnya ia merujuk kepada niat. Ini kerana Al-Ghazali telah menjelaskan bahawa "niat adalah situasi kejiwaan yang berada ditengah tadi, iaitu tergeraknya hati (niat) menuruti penetapan kemahuan (sikap) dan kecenderungan ke arah yang sesuai dengan tujuan baik sekarang (gelagat) mahupun yang akan datang (gelagat)". 
Ini bertepatan dengan hadis Rasulullah S.A.W di atas yang menerangkan bahawa setiap gelagat manusia pastinya berdasarkan kepada niat. Terdapat keperluan untuk memahami konsep niat AlGhazali kerana terdapat kecenderungan dari para pengkaji yang cuba memahami gelagat pengguna muslim dari perspektif barat seperti dinyatakan sebelum ini. Dengan menggunakan konsep niat AlGhazali, secara langsungnya dapat meningkatkan penggunaan konsep niat Al-Ghazali yang lebih selari dengan kehidupan seorang muslim.

\section{PERKAITAN FAKTOR KEMAHUAN/ SIKAP, MANFAAT TANGGAPAN DAN HALANGAN KEPADA NIAT}

Sikap merupakan faktor utama yang memberi kesan kepada minat meminjam seseorang. Dalam konteks sikap PKSP terhadap pinjaman, tidak banyak diketahui kerana hanya terdapat dua kajian yang telah dilakukan (Martin et al. 2015; Ramli 2013). Misalnya, Ramli (2013) mendapati sebahagian PKSP bersikap negatif untuk melabur walaupun memperolehi pendapatan lumayan semasa harga BTS tinggi, namun mereka tetap tidak membaja kelapa sawit. Manakala Martin et al. (2015) pula mendapati PKSP jenis off-farm bersikap positif untuk melabur melalui pinjaman berbanding PKSP jenis on-farm yang bersikap negatif terhadap kemudahan pinjaman. Walau bagaimanapun, kedua-dua kajian bersifat kualitatif dan tidak diketahui kekuatan pengaruh sikap PKSP kepada keinginan PKSP untuk melanggan pinjaman pertanian seperti mikro kredit.

Terdapat banyak kajian yang mendapati sikap merupakan faktor utama yang yang menyumbang kepada niat individu untuk melaksanakan sesuatu perkara. Misalnya, Gopi dan Ramayah (2007) mendapati sikap signifikan mempengaruhi niat pelanggan melakukan perniagaan secara maya (online trading). Di perbankan Islam pula, Alam et al. (2012) mendapati masyarakat muslim di Lembah Klang mempunyai sikap positif untuk menerima pembiayaan perumahan secara Islam. Begitu juga Amin (2016) mendapati sikap positif merupakan faktor utama yang mempengaruhi niat pelanggan untuk melabur dalam akaun pelaburan emas di perbankan Islam. Berdasarkan perbincangan di atas, hipotesis yang ingin diuji ialah:

H1: Dijangkakan sikap terhadap mikro kredit signifikan secara positif mempengaruhi niat melanggan mikro kredit di perbankan Islam.
Walaupun institusi perbankan Islam meletakkan terma dan syarat yang ketat, namun tidak dapat dinafikan mikro kredit turut memberi manfaat kepada diri dan keluarga PKSP. Secara lumrahnya, manusia hanya berkelakuan tertentu jika mendapat manfaat. Begitu juga dengan PKSP, mereka hanya akan melanggan mikro kredit setelah percaya mikro kredit memberi manfaat yang lebih banyak berbanding risiko yang bakal diterima. Dari sudut psikologi, kejayaan sesuatu produk yang direka oleh perbankan Islam bergantung kepada persepsi pengguna. Sekiranya produk yang diperkenalkan lebih banyak mendatangkan kebaikan berbanding kemudaratan, maka produk tersebut mempunyai kebarangkalian yang tinggi untuk diterima. Sebelum ini, terdapat kajian yang mendapati golongan miskin percaya mikro kredit mampu meningkatkan pendapatan mereka (Coleman 2006; Meyer 2013). Keyakinan golongan miskin bahawa mikro kredit mampu meningkatkan pendapatan ada asasnya, hal ini kerana mereka telah melihat kejayaan rakanrakan yang melanggan mikro kredit dari AIM (Saad 2011). Dengan adanya contoh kejayaan individu mengambil pinjaman mikro kredit dari AIM, ia mendorong anggota masyarakat untuk mempercayai bahawa mikro kredit memberi manfaat kepada mereka. Menjangkakan manfaat yang bakal diterima turut dikenali sebagai manfaat tanggapan. Manfaat tanggapan merupakan penilaian faedah yang bakal diterima oleh individu daripada perbuatan yang akan dilakukan. Oleh itu Leung (2013) menyatakan manfaat tanggapan merujuk kepada persepsi kesan positif yang lahir dari tindakan tertentu. Dalam konteks PKSP, terdapat dua jenis manfaat yang bakal diterima dari mikro kredit iaitu manfaat langsung (modal kewangan mencukupi - mampu membeli baja dan peralatan) dan manfaat tidak langsung (hasil pengeluaran meningkat-taraf kehidupan dan kebajikan isi rumah meningkat).

Faktor manfaat tanggapan turut dikaji kesannya kepada pembentukan sikap dan niat. Misalnya Lee (2009) telah mengkaji kesan manfaat tanggapan kepada sikap dan niat, dan didapati manfaat tanggapan mempengaruhi mempengaruhi sikap dan niat menggunakan perbankan internet. Begitu juga Chin et al. (2016) turut mendapati manfaat tanggapan signifikan mempengaruhi sikap dan niat PKSP di Malaysia menjadi pembekal sisa kelapa sawit kepada pasaran biomas. Di perbankan Islam pula, Amin (2016) dan Amin et al. (2016) turut mendapati manfaat tanggapan signifikan mempengaruhi niat 
pelanggan memilih produk pembiayaan rumah dan membuka akaun pelaburan emas di perbankan Islam. Manakala dalam konteks mikro kredit, manfaat tanggapan telah diuji kesannya kepada niat individu untuk mengambil pinjaman mikro kredit (Jebarajakirthy \& Lobo 2015; Jebarajakirthy \& Thaichon 2016; Jebarajakirthy, C. Lobo \& Hewege 2014; Jebarajakirthy, Lobo \& Hewege 2015; Ziyi \& Huifan 2016) tetapi belum pernah diuji pengaruhnya kepada sikap pelanggan. Justeru hipotesis yang ingin diuji ialah:

H2: Dijangkakan manfaat tanggapan signifikan secara positif mempengaruhi niat melanggan mikro kredit di perbankan Islam.

H3: Dijangkakan manfaat tanggapan signifikan secara positif mempengaruhi sikap terhadap mikro kredit.

Pihak bank menetapkan syarat-syarat pinjaman untuk memastikan pinjaman yang diberi mampu dikutip semula. Dari sudut pandang pelanggan pula, syarat-syarat pinjaman yang dikenakan oleh bank merupakan penghalang untuk mereka mendapatkan kemudahan kredit (Turvey \& Kong 2010; Jose, Rugimbana \& Gatfield 2012). Pelanggan sangat peka mengenai halangan yang terdiri daripada kadar faedah, caj perkhidmatan, cagaran, dokumen sokongan dan tempoh proses permohonan (Turvey \& Kong 2010; Jose et al. 2012). Faktor halangan didapati memberi kesan negatif kepada niat melanggan mikro kredit (Jebarajakirthy \& Lobo 2015; Jebarajakirthy \& Thaichon 2016; Jebarajakirthy et al. 2014; Jebarajakirthy et al. 2015; Ziyi \& Huifan 2016). Terdapat juga kajian yang mendapati halangan bukan sahaja memberi kesan kepada niat individu, malah ia juga turut membetuk sikap individu (Amin et al. 2010). Berdasarkan perbincangan di atas, hipotesis yang ingin diuji ialah:

H4: Dijangkakan faktor halangan signifikan secara negatif mempengaruhi niat melanggan mikro kredit.

H5: Dijangkakan faktor halangan signifikan secara negatif mempengaruhi sikap terhadap mikro kredit.

\section{KERANGKA KONSEPTUAL}

Berdasarkan kupasan kajian lepas dan hubungan hipotesis yang dibincangkan, model kajian yang digunakan ditunjukkan pada Rajah 1.

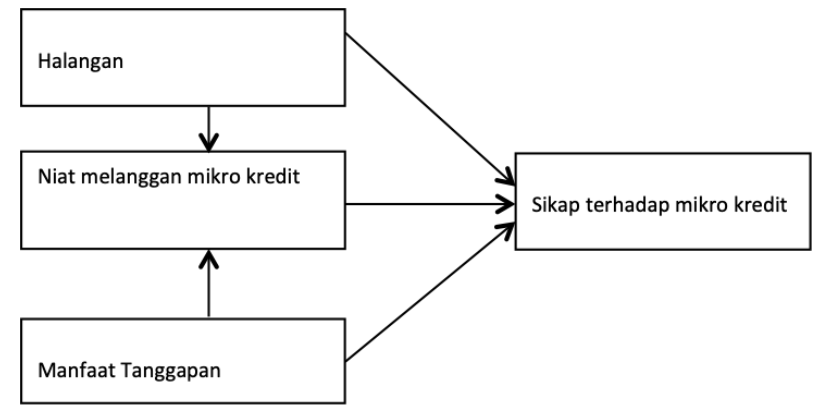

RAJAH 1. Model kajian

\section{METHODOLOGI}

Pendekatan kajian yang digunakan dalam kajian ini adalah keratan rentas. Menurut Shaughnessy et al. (2012) pendekatan keratan rentas sesuai digunakan apabila untuk mengetahui perubahan sikap atau gelagat manusia yang disebabkan oleh sesuatu perkara atau isu yang timbul. Sehubungan dengan itu, pendekatan keratan rentas yang digunakan dalam konteks kajian ini adalah bersesuaian dengan tujuan kajian iaitu memahami faktor yang menyumbang kepada sikap dan kecenderungan melanggan mikro kredit dalam kalangan PKSP. Kajian ini dilaksanakan di daerah Hilir Perak, Malaysia yang melibatkan seramai 362 orang PKSP yang berumur antara 18 hingga 60 tahun. Oleh kerana data kajian dianalisis menggunakan SEM, saiz sampel adalah mencukupi kerana berada antara 250 hingga 500 (Schumacker \& Lomax 2010). Setiap daerah di negeri Perak dibahagikan mengikut mukim-mukim tertentu yang ditadbir oleh seorang penghulu, kajian ini menggunakan pensampelan berkelompok dalam mengutip data bagi mewakili 5 mukim yang terdapat di daerah Hilir Perak. Daerah ini bukan sahaja menjadi salah satu jelapang padi negeri Perak, bahkan daerah ini mencatatkan jumlah PKSP paling ramai berbanding daerah lain di negeri Perak (Perlesenan MPOB 2016). Walaupun daerah ini bertanah subur, namun produktiviti BTS bagi PKSP sangat rendah yang menyebabkan mereka berpendapatan kurang dari RM2,500.00 sebulan (Awang et al. 2016). Hal ini terbukti apabila hanya $1.6 \%$ daripada PKSP di daerah ini berjaya mencapai pengeluaran BTS sehingga 30 tan/hektar/ tahun (Awang et al. 2016). Justeru majoriti PKSP di daerah ini tergolong dalam B40 dan mempunyai masalah modal kewangan untuk memajukan ladang kelapa sawit yang diusahakan. Ciri-ciri responden ditunjukkan dalam Jadual 2. 
JADUAL 2. Respondents information $(n=362)$

\begin{tabular}{llll}
\hline Perkara & Peratusan & Perkara & Peratusan \\
\hline 1. Jantina: & & 2. Status perkahwinan: & \\
Lelaki & 85.0 & Bujang & 3.6 \\
Perempuan & 15.0 & Berkahwin & 87.5 \\
& & Duda/janda & 8.9
\end{tabular}

3. Umur:

Kurang 31 tahun

31 tahun -35 tahun

36 tahun -40 tahun

41 tahun -45 tahun

46 tahun -50 tahun

51 tahun -55 tahun

56 tahun -60 tahun

Tidak dilapor

5. Taraf pendidikan:

Tidak bersekolah

Sekolah rendah

SRP/PMR

SPM/SPMV

STPM/HSC

Diploma

Sarjana muda dan ke atas

\subsection{1 \\ 8.56 \\ 15.19 \\ 20.44 \\ 19.90 \\ 12.43 \\ 8.84 \\ 12.43}

4. Pekerjaan Utama:

Bertani $\quad 40.2$

Berniaga $\quad 15.5$

Kakitangan swasta $\quad 13.9$

Kakitangan kerajaan $\quad 15.0$

Pesara kerajaan $\quad 2.5$

Lain-lain $\quad 13.0$
6. Pendapatan Bulanan:

$\begin{array}{ll}\text { Kurang RM1,000 } & 17.7 \\ \text { RM1,000 - RM1,500 } & 27.4 \\ \text { RM1,501 - RM2,000 } & 20.5 \\ \text { RM2,001 - RM2,500 } & 14.1 \\ \text { RM2,501 - RM3,000 } & 7.5 \\ \text { RM3,001 - RM3,500 } & 3.3 \\ \text { RM3,501 - RM4,000 } & 2.8 \\ \text { Lebih RM4,000 } & 6.6\end{array}$

8. Pengalaman:

1 tahun -5 tahun $\quad 22.65$

6 tahun -10 tahun $\quad 28.45$

11 tahun -15 tahun $\quad 18.52$

16 tahun -20 tahun $\quad 9.67$

21 tahun -25 tahun $\quad 4.97$

26 tahun -30 tahun $\quad 3.04$

Lebih 30 tahun $\quad 0.55$

Tidak dilapor $\quad 12.15$
Item bagi konstruk niat diadaptasi dari (Amin et al. 2011; Jebarajakirthy et al. 2015). Manakala item bagi konstruk sikap diadaptasi daripada (Amin et al. 2011; Jebarajakirthy \& Thaichon 2016). Item bagi manfaat tanggapan dibina sendiri dan diadaptasi daripada (Jebarajakirthy \& Thaichon 2016). Item bagi kontruk halangan diadaptasi daripada (Jebarajakirthy \& Lobo 2015). Semua item dibina dalam bentuk pernyatakan dan diukur menggunakan skala likert 10 iaitu 1 sangat tidak setuju hingga 10 sangat bersetuju. Confirmatory factor analysis - CFA telah digunakan untuk mengesahkan item yang digunakan mampu mengukur model kajian (Hair et al. 2010). Rajah 1 melaporkan keputusan fitness indexes bagi ujian CFA dan mencapai tahap yang ditetapkan iaitu RMSEA $=0.059, \mathrm{GFI}=0.935, \mathrm{CFI}=0.983$ dan $\mathrm{ChiSq} /$ $\mathrm{df}=2.260$ (Hair et al. 2010; Zainudin 2015). Jadual 3 pula melaporkan keputusan ujian kebolehpercayaan komposit (CV), avarage variance extracted (AVE) dan korelasi antara konstrak. Selain itu, data kajian juga bertaburan normal kerana nilai skewness berada antara -1 hingga 1 dan nilai critical region bagi skewness kurang dari 8.0 (Zainudin 2015). Keputusan-keputusan ujian yang dijalankan ini berjaya membuktikan data kajian sesuai untuk dianalisis pada peringkat seterusnya menggunakan SEM.

Perisian SPSS-AMOS 21 digunakan untuk menganalisis data bagi menguji hipotesis yang dibangunkan. Rajah 2 menunjukkan sikap terhadap mikro kredit, manfaat tanggapan dan faktor halangan menerangkan sebanyak $45 \%\left(\mathrm{R}^{2}=0.45\right)$ varian ke atas niat melanggan mikro kredit di perbankan Islam. Manakala faktor risiko dan manfaat tanggapan menerangkan sebanyak $42 \%\left(\mathrm{R}^{2}=0.42\right)$ varian ke atas sikap terhadap mikro kredit di perbankan Islam. Seterusnya, Jadual 4 melaporkan keputusan bagi setiap hipotesis. 


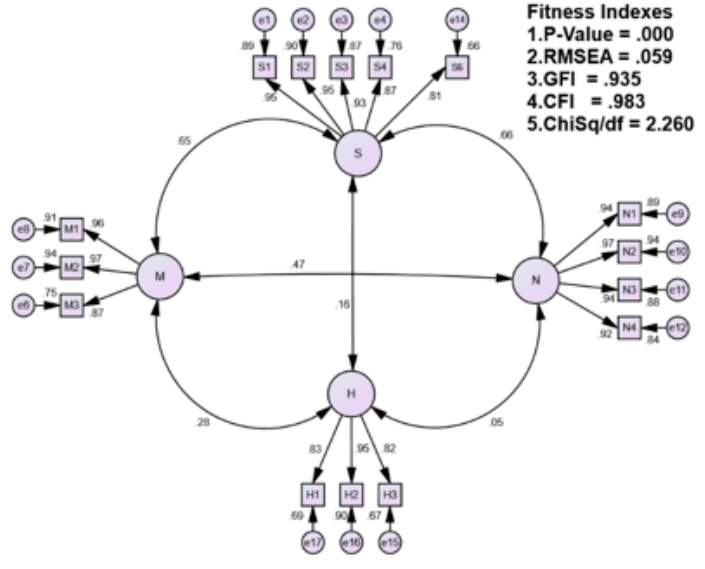

$\mathrm{S}=$ sikap; $\mathrm{M}=$ Manfaat tanggapan; $\mathrm{H}=$ Halangan; $\mathrm{N}=\mathrm{Niat}$ RAJAH 1: Keputusan fitness indexes bagi CFA

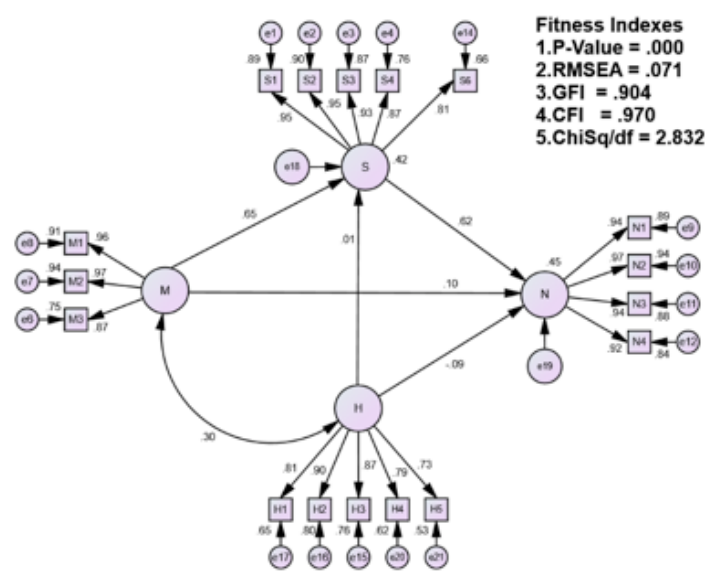

$\mathrm{S}=$ sikap; $\mathrm{M}=$ Manfaat tanggapan; $\mathrm{H}=$ Halangan; $\mathrm{N}=\mathrm{Niat}$ RAJAH 2. Keputusan analisis SEM (unstandardized)

\section{PERBINCANGAN DAN IMPLIKASI}

Berdasarkan hipotesis yang dikemukan, didapati sikap terhadap mikro kredit (H1) dan faktor halangan (H4) signifikan mempengaruhi niat, namun manfaat tanggapan (H2) didapati tidak signifikan. Ini bererti PKSP mempunyai sikap positif untuk melanggan mikro kredit, tetapi perbankan islam sukar memberi pinjaman kepada mereka. Halangan yang terdiri daripada syarat pinjaman yang ketat dan dokumen sokongan yang pelbagai ternyata merencatkan niat PKSP untuk melanggan mikro kredit. Dapatan kajian ini selari dengan (Saqib, Ahmad, \& Panezai 2016; Jebarajakirthy \& Lobo 2015). Saqib et al. (2016) mendapati petani di Pakistan sukar mendapatkan pinjaman kerana institusi perbankan menetapkan syarat yang ketat dan dokumen sokongan yang pelbagai. Begitu juga Jebarajakirthy dan Lobo (2015) yang menganalisa data kajian menggunakan SEM mendapati faktor halangan signifikan negatif kepada niat belia di Bangladesh untuk melanggan mikro kredit, beliau turut mendapati golongan belia beranggapan mikro kredit kurang bemanfaat untuk meningkatkan kualiti kehidupan.

Manfaat tanggapan (H3) signifikan memberi kesan kepada pembentukkan sikap terhadap mikro kredit, tetapi faktor halangan (H5) tidak signifikan. Keputusan kajian ini menyokong idea yang dikemuka oleh Al-Ghazali yang menyatakan kemahuan/sikap seseorang berdasarkan tanggapan seseorang terhadap sesuatu perkara (Al-Ghazali, 1994). Dapatan kajian ini menjelaskan bahawa pertimbangan manfaat

JADUAL 3: Keputusan ujian kebolehpercayaan komposit (CV), avarage variance extracted (AVE) dan korelasi.

\begin{tabular}{ccccccc}
\hline & CR & AVE & S & M & N & H \\
\hline S & 0.949 & 0.789 & 0.889 & & & \\
M & 0.948 & 0.859 & $0.67^{* * *}$ & 0.927 & & \\
N & 0.963 & 0.866 & $0.70^{* * *}$ & $0.54^{* * *}$ & 0.931 & $-0.05 \mathrm{~ns}$ \\
H & 0.898 & 0.746 & $-0.16^{* *}$ & $-0.22^{* * *}$ & 0.864 \\
\hline
\end{tabular}

Significance of Correlations: $* * * \mathrm{p}<0.001 ; * * \mathrm{p}<0.010 ; * \mathrm{p}<0.050 ;{ }^{\text {ns }} \mathrm{p}<0.100 ; \mathrm{S}=$ sikap; $\mathrm{M}=$ manfaat tanggapan; $\mathrm{N}=$ niat melanggan mikro kredit; $\mathrm{H}=$ halangan; $\mathrm{CR}=$ composite reliability; $\mathrm{AVE}=$ avarage variance extracted

JADUAL 4. Keputusan ujian hipotesis dan level signifikan

\begin{tabular}{ccccccc}
\hline Hip & Const & Path & Const & Estimate & C.R. & P \\
\hline H1 & $\mathrm{S}$ & $\rightarrow$ & $\mathrm{N}$ & 0.68 & 10.77 & $* * *$ \\
$\mathrm{H} 2$ & $\mathrm{M}$ & $\rightarrow$ & $\mathrm{N}$ & 0.09 & 1.70 & 0.09 \\
$\mathrm{H} 3$ & $\mathrm{M}$ & $\rightarrow$ & $\mathrm{S}$ & 0.59 & 13.86 & $* * *$ \\
$\mathrm{H} 4$ & $\mathrm{H}$ & $\rightarrow$ & $\mathrm{N}$ & -0.12 & -2.12 & 0.03 \\
H5 & $\mathrm{H}$ & $\rightarrow$ & $\mathrm{S}$ & 0.01 & 0.21 & 0.84 \\
\hline
\end{tabular}

$\mathrm{S}=$ sikap; $\mathrm{M}=$ Manfaat tanggapan; $\mathrm{H}=$ Halangan; $\mathrm{N}=$ Niat $; * * * \mathrm{p}<0.001 ;{ }^{* *} \mathrm{p}<0.010 ;{ }^{*} \mathrm{p}<0.050 ;{ }^{\text {ns }} \mathrm{p}<0.100$ 
oleh PKSP mampu membentuk sikap positif, tetapi faktor halangan bukanlah faktor terpenting yang membentuk sikap PKSP terhadap mikro kredit. Walaupun manfaat tanggapan berjaya membentuk sikap positif PKSP terhadap mikro kredit, namun ia bukanlah pendorong yang kuat kepada niat PKSP untuk mengambil mikro kredit. Sebaliknya, faktor halangan didapati memainkan peranan yang lebih besar kerana ia memberi impak secara langsung kepada niat PKSP. Hal ini menjelaskan bahawa walaupun PKSP mempunyai kecenderungan untuk melanggan mikro kredit, namun niat tersebut menjadi terencat disebabkan syarat dan terma yang dikenakan oleh institusi perbankan Islam.

Berdasarkan data soal selidik yang diterima, kertas ini membuat kesimpulan bahawa minat melanggan mikro kredit dalam kalangan PKSP merosot kerana mereka sukar memenuhi syarat dan terma yang ditetapkan oleh institusi perbankan Islam. Analisis yang dilakukan berjaya membuktikan bahawa mikro kredit yang disediakan oleh perbankan Islam hanya mampu membentuk persepsi masyarakat bahawa mikro kredit memberi kebaikan, tetapi PKSP masih gagal memanfaatkan kemudahan mikro kredit kerana halangan yang dikenakan kepada mereka sukar untuk dipenuhi. Berpandukan Jadual 1, ciri-ciri produk mikro kredit yang disediakan oleh institusi perbankan Islam tidak menarik serta syaratnya kurang sesuai dikenakan kepada PKSP (BNM 2016). Misalnya, masih terdapat institusi perbankan Islam yang mengenakan kadar keuntungan sehingga $24 \%$ setahun. Selain itu, terdapat juga institusi perbankan Islam yang mensyaratkan PKSP mempunyai lesen perniagaan dari Suruhanjaya Syarikat Malaysia (SSM). Wal hal PKSP tidak memerlukan lesen perniagaan untuk menjual BTS, ini kerana pihak kerajaan hanya mensyaratkan memiliki lesen menjual BTS dari MPOB.

Dapatan ini mempunyai implikasi penting kepada pembuat dasar dan pemain industri. Pihak kerajaan perlu membangunkan sistem bayaran balik effisyen yang melibatkan pihak bank, PKSP dan syarikat yang membeli buah kelapa sawit dari PKSP. Ini boleh dilaksanakan kerana setiap PKSP wajib memiliki lesen menjual buah kelapa sawit daripada MPOB. Bayaran ansuran akan dipotong oleh syarikat apabila PKSP menjual bual kelapa sawit berdasarkan jumlah tertentu seperti yang ditetapkan oleh bank. Manakala implikasi kajian kepada pihak bank ialah dapat memahami faktor psikologi dari perspektif pelanggan mikro kredit. Justeru penambahbaikan ciri-ciri produk mikro kredit boleh dilakukan supaya mikro kredit dapat dimanafaatkan untuk meningkatkan kualiti kehidupan golongan petani dan pekebun.

\section{KESIMPULAN}

Kertas ini membuktikan konsep niat yang diperkenalkan oleh Al-Ghazali sesuai digunakan untuk memahami gelagat pengguna. Sehingga hari ini, teori yang dikemuka oleh sarjana tersohor muslim kurang mendapat sambutan. Sebaliknya, teori atau model yang dikemuka oleh sarjana barat lebih mendapat sambutan dan diguna pakai untuk memahami gelagat pengguna. Misalnya, TGT telah digunakan oleh pengkaji muslim dan non-muslim untuk memahami gelagat pengguna. Antara sebab teori barat lebih diterima kerana dibuktikan secara empirikal oleh pengkaji barat. Sebaliknya, teori yang diperkenalkan oleh sarjana muslim seperti Al-Ghazali belum dibuktikan secara empirikal. Justeru, kajian ini menyumbang kepada dunia ilmu kerana berjaya membuktikan konsep niat AlGhazali sesuai diangkat sebagai teori dan perlu dikembangan melalui pembuktian secara empirikal. Dalam kontek kajian ini, konsep niat Al-Ghazali berjaya menjelaskan fenomena sebab PKSP enggan untuk melanggan mikro kredit yang disediakan oleh institusi perbankan Islam.

Antara limitasi yang wujud dalam kajian ini ialah tidak semua konstruk yang dibincangkan oleh Al-Ghazali mengenai konsep niat digunakan dalam kajian ini seperti nilai beragama, kemampuan diri dan risiko. Sehubungan dengan itu, dicadangkan kajian lanjutan turut melibatkan konstruk nilai beragama, kemampuan diri dan risiko supaya dapatan kajian lebih komprehensif. Faktor-faktor lain yang tidak dikaji merupakan perkara penting yang perlu diberi perhatian kerana turut mempengaruhi strategi pemasaran institusi perbankan Islam. Limitasi kedua pula ialah data kajian tidak melibatkan golongan petani lain seperti pesawah, penoreh getah dan pekebun sayur. Golongan-golongan ini juga turut menghadapi masalah ketidakcukupan modal kerja untuk meningkatkan produktiviti tanaman mereka. Justeru, kajian lanjutan diperlukan untuk mengetahui faktor-faktor yang mempengaruhi sikap dan niat mereka untuk melanggan mikro kredit. Apabila faktor-faktor yang mempengaruhi sikap dan niat golongan petani lain diketahui, ini memudahkan lagi penambahbaikan ciri-ciri produk dilakukan oleh institusi perbankan Islam. 
Oleh itu, disarankan kajian lanjutan turut memberi fokus kepada golongan petani lain seperti pesawah, penoreh getah dan pekebun sayur. Kajian lanjutan yang melibatkan golongan petani lain sangat mustahak bagi membantu institusi perbankan Islam memahami secara komprehensif sikap dan niat petani terhadap mikro kredit. Ini membantu institusi perbankan Islam menambah baik ciri-ciri produk dan merangka pelan pemasaran secara komprehensif supaya kos pemasaran dapat dijimatkan.

\section{PENGHARGAAN}

Ini merupakan sebahagian daripada tesis $\mathrm{PhD}$ penulis kedua yang dibiayai dari geran Universiti Kebangsaan Malaysia MPOB EP-2015-063. Jutaan terima kasih juga kepada Geran GUP UKM (GUP2017-119) yang turut menyumbang dana untuk penerbitan artikel ini.

\section{RUJUKAN}

Ab Aziz, M. R. B. 2011. Opportunity for agro entrepreneur in developing agro initiative in Islamic banking in Malaysia. Journal of Animal and Plant Sciences 21(2) 290-302.

Al-Bukhari, M. I. 1993. Sahih al-Bukhari. Dar Ibn Kathir.

Al-Ghazali. 1988. Ihya Ulumiddin. Edisi pertama, disunting oleh, Ismail Yaakub. Victory Ajensi.

Al-Ghazali. 1994. Imam Al Ghazali Berbicara tentang Niat, Ikhlas dan Jujur. Edisi pertama, disunting oleh, A. Sunarto, A. Huda, \& M. Yasin.

Al-Qardhawi, Y. 2004. Konsep Niat \& Ikhlas Menurut Islam. Edisi pertama, disunting oleh, K. Suhardi. Pustaka Syuhada.

Alam, S. S., Janor, H., Zanariah, Wel, C. A. C., \& Ahsan, M. N. 2012. Is religiosity an important factor in influencing the intention to undertake Islamic home financing in Klang Valley? World Applied Sciences Journal 19(7): 1030-1041. https://doi.org/10.5829/ idosi.wasj.2012.19.07.392

Amin, H. 2016. Willingness to open Islamic gold investment accounts. Journal of Internet Banking and Commerce 21(1): 1-17.

Amin, H., Abdul-Rahman, A.-R., \& Abdul-Razak, D. 2016. Malaysian consumers' willingness to choose Islamic mortgage products. International Journal of Bank Marketing 34(6): 868-884. https://doi.org/10.1108/ IJBM-06-2015-0099

Amin, H., Ghazali, M. F., \& Supinah, R. 2010. Determinants of Qardhul Hassan financing acceptance among Malaysian bank customers: An empirical analysis. International Journal of Business and Society 11(1): 1-16.

Amin, H., Rahim Abdul Rahman, A., Laison Sondoh, S. \& Magdalene Chooi Hwa, A. 2011. Determinants of customers' intention to use Islamic personal financing. Journal of Islamic Accounting and Business Research 2(1): 22-42. https://doi. org/10.1108/17590811111129490
Awang, A. H., Hashim, K., Ramli, Z., Lyndon, N., Ibrahim, I., Peng, T. S., Johari, M. A., Basaruddin, N. H., Hamid, M. H. A., \& Yusof, I. 2016. Pemindahan teknologi dan produktiviti pekebun kecil persendirian sawit di Teluk Intan, Perak. Journal of Social Sciences and Humanities, September (1): 78-87.

Ayat K, A. R., Ramli, A., Faizah, M. S., \& Mohd Ariff, S. 2008. The Malaysian palm oil supply chain: the role of the independent smallholder. Oil Palm Industry Economic Journal 8(2): 17-27.

Azman, I., Mohd Arif, S., \& M. Mohd, N. 2003. The Production Cost of Oil Palm Fresh Fruit Bunches : the Case of Independent Smallholders in Johor. Oil Palm Industry Economic Journal 3(1): 1-7.

Bank Negara Malaysia. 2011. Financial Sector Blueprint 2011-2020.

Belcher, B., Imang, N., \& Achdiawan, R. 2004. Rattan, rubber, or oil palm: Cultural and financial considerations for farmers in Kalimantan. Economic Botany 58(sp1): S77-S87.

BNM. 2016. Jadual perbandingan ciri-ciri produk pembiayaan mikro. https:/www.bnm.gov.my/documents/ sme/bm_Comparative_Table_20160511.pdf

Chin, H.-C., Choong, W.-W., Sharifah Rafidah, W. A., \& Abdul Hakim, M. 2016. Using Theory of Planned Behaviour to explore oil palm smallholder planters' intention to supply oil palm residues. Journal of Cleaner Production 126: 428-439.

Claudine, N., \& Reza, A. 2012. A review of smallholder oil palm production: Challenges and opportunities for enhancing sustainability- A Malaysian perspective. Journal of Oil Palm and the Environment 3(12): 114-120.

Coleman, B. E. 2006. Microfinance in Northeast Thailand: Who benefits and how much? World Development 34(9): 1612-1638. https://doi.org/10.1016/j. worlddev.2006.01.006

Cramb, R. A. \& Sujang, P. S. 2013. The mouse deer and the crocodile: oil palm smallholders and livelihood strategies in Sarawak, Malaysia. Journal of Peasant Studies 40(1): 129-154. https://doi.org/10.1080/0306 6150.2012 .750241$.

Gopi, M., \& Ramayah, T. 2007. Applicability of theory of planned behavior in predicting intention to trade online. International Journal of Emerging Markets 2(4): 348-360. https://doi.org/10.1108/17468800710824509.

Hair, J. F., Black, W. C., Babin, B. J., \& Anderson, R. E. 2010. Multivariate Data Analysis. $7^{\text {th }}$ edition. Prentice Hall.

Han, Z., Yeoh, K. K., \& Ahmad, W. M. B. W. 2017. An empirical investigation of Chinese Muslims' intention to adopt Islamic banking services in Western China. Advanced Science Letters 23(9): 8741-8746. https:// doi.org/10.1166/asl.2017.9962

Haque, A., Anwar, N., Tarofder, A. K., Ahmad, N. S., \& Sharif, S. R. 2018. Muslim consumers' purchase behavior towards halal cosmetic products in Malaysia. Management Science Letters 1305-1318. https://doi. org/10.5267/j.msl.2018.9.009

Jebarajakirthy, C., C. Lobo, A. \& Hewege, C. 2014. Investigating determinants of youth's intentions of seeking microcredit in the post-conflict era. Asia Pacific Journal of Marketing and Logistics 26(4): 579-601. https://doi.org/10.1108/APJML-03-2014-0039 
Jebarajakirthy, C. \& Lobo, A. 2015. A study investigating attitudinal perceptions of microcredit services and their relevant drivers in bottom of pyramid market segments. Journal of Retailing and Consumer Services 23: 39-48. https://doi.org/10.1016/j.jretconser.2014.12.005

Jebarajakirthy, C., Lobo, A. \& Hewege, C. 2015. Enhancing youth's attitudes towards microcredit in the bottom of the pyramid markets. International Journal of Consumer Studies 39(2): 180-192. https:// doi.org/10.1111/ijcs.12166.

Jebarajakirthy, C., \& Thaichon, P. 2016. Marketing microcredit to bottom of the pyramid market. International Journal of Bank Marketing 34(2): 191-215. https://doi.org/10.1108/IJBM-12-2014-0176.

Jose, S., Rugimbana, R., \& Gatfield, T. 2012. Consumer responses to CSR driven microfinance strategy of banks - An empirical investigation based on India. International Journal of Business and Management 7(21): 1-14. https://doi.org/10.5539/ijbm.v7n21p1.

Kashif, M. \& De Run, E. C. 2015. Money donations intentions among Muslim donors: an extended theory of planned behavior model. International Journal of Nonprofit and Voluntary Sector Marketing 20(1): 84-96. https://doi.org/10.1002/nvsm.1519.

Kementerian Kemajuan Luar Bandar dan Wilayah. 2010. Pelan Induk Pembangunan Luar Bandar.

Kementerian Perusahaan Perladangan dan Komoditi. 2016. Laporan tahunan MPIC 2015.

Lee, M.-C. 2009. Factors influencing the adoption of internet banking: An integration of TAM and TPB with perceived risk and perceived benefit. Electronic Commerce Research and Applications 8(3): 130-141. https://doi.org/10.1016/j.elerap.2008.11.006

Leung, Y. 2013. Perceived benefits. In Encyclopedia of Behavioral Medicine, 1450-1451. New York: Springer. https://doi.org/10.1007/978-1-4419-1005-9 1165

Maizaitulaidawati, M.H., \&Asmak,A. R. 2016. Do Muslims intend to participate in Islamic insurance? Journal of Islamic Accounting and Business Research 7(1): 42-58. https://doi.org/10.1108/JIABR-03-2014-0012

Majlis Penasihat Ekonomi Negara. 2010. Model Baru Ekonomi untuk Malaysia. Percetakan Nasional Malaysia Berhad. www.neac.gov.my

Martin, S., Rieple, A., Chang, J., Boniface, B., \& Ahmed, A. 2015. Small farmers and sustainability: Institutional barriers to investment and innovation in the Malaysian palm oil industry in Sabah. Journal of Rural Studies 40: 46-58. https://doi.org/10.1016/j.jrurstud.2015.06.002

Meyer, R. L. 2013. Microcredit and agriculture: Challenges, successes and prospects. In Microfinance in Developing Countries, 199-226. Palgrave Macmillan UK. https:// doi.org/10.1057/9781137301925 10

Muhammad Hakimi, M. S. \& Mūhammad Rizki, M. 2015. Financial problems among farmers in Malaysia: Islamic agricultural finance as a possible solution. Asian Social Science 11(4): 1-16. https://doi.org/10.5539/ ass.v $11 \mathrm{n} 4 \mathrm{p} 1$

Muslim, I. A. 1984. al-Jami' al-Sahih. Dar Ihya' Turas al-Arabi.

Nkongho, R. N., Feintrenie, L., \& Levang, P. 2014. Strengths and weaknesses of the smallholder oil palm sector in Cameroon. OCL 21(2): D208. https://doi. org/10.1051/ocl/2013043
PEMANDU. 2010. Chapter 9: Deepening Malaysia's Palm Oil Advantage (pp. 281-314). PEMANDU.

Perlesenan MPOB. 2016. Nisbah bilangan peniaga buah sawit berbanding dengan keluasan tanaman kelapa sawit pekebun kecil sehingga Februari 2016.

Ramli, A. (2013). Technical efficiency of Independent Oil Palm Smallholders ( ISH ) in Peninsular Malaysia with respect to fertiliser and land size. Oil Palm Industry Economic Journal 13(2): 27-37.

Saad, N. 2011. Selecting high-income generating activities for micro-entrepreneurs : The case study of Amanah Ikhtiar Malaysia. International Journal of Humanities and Social Science 1(5): 258-264.

Saqib, S. E., Ahmad, M. M. \& Panezai, S. 2016. Landholding size and farmers' access to credit and its utilisation in Pakistan. Development in Practice 26(8): 1060-1071. https://doi.org/10.1080/0961452. 2016.1227301

Schumacker, R. E., \& Lomax, R. G. 2010. A Beginner's Guide to Structural Equation Modeling. $3^{\text {rd }}$ edition. Taylor \& Francis.

Shaughnessy, J. J., Zechmeister, E. B. \& Zechmeister, J. S. 2012. Research Methods in Psychology. $9^{\text {th }}$ edition. McGraw-Hill.

Siwar, C., Mohd Khairi, I., Nurul Ashikin, A. \& Siti Zalikha, Z. 2019. Kumpulan Isi Rumah Berpendapatan 40 Peratus Terendah ( B40) Di Malaysia: Mengenal Pasti Trend, Ciri, Isu dan Cabaran.

Soon, J. M. \& Wallace, C. 2017. Application of theory of planned behaviour in purchasing intention and consumption of Halal food. Nutrition \& Food Science, 47(5), 635-647.https://doi.org/10.1108/NFS-03-2017-0059

Turvey, C. G., \& Kong, R. (2010). Informal lending amongst friends and relatives: Can microcredit compete in rural China? China Economic Review 21(4): 544-556. https://doi.org/10.1016/j.chieco.2010.05.001

Zainudin, A. 2015. SEM Made Simple: A Gentle Approach to learning Structural Equation Modelling. MPWS Rich Publication.

Zinser, B. A. 2018. Retail Islamic banking and financial services. Journal of Islamic Marketing, JIMA-07-20170074. https://doi.org/10.1108/JIMA-07-2017-0074

Ziyi, F. \& Huifan, L. 2016. A study on BOP customers' attitudes toward microfinance and their driving factors: The evidence from China's rural households. $3^{\text {rd }}$ International Conference on Service Systems and Service Management, ICSSS 2016.

Muhammad Hakimi Mohd. Shafiai

Pusat Pengajian Ekonomi

Fakulti Ekonomi dan Pengurusan

Universiti Kebangsaan Malaysia

43600 Bangi

Selangor

Malaysia

Institut Islam Hadhari, Universiti

Kebangsaan Malaysia, 43600

UKM Bangi

Selangor

Malaysia

hakimi@ukm.edu.my 
Syahrul Anuar Ali

Sekolah Muamalat dan Pengurusan

Kolej Pengajian Islam Johor

Jalan Heman, Kg. Aman, Larkin Jaya

80350 Johor Bahru

Johor

Malaysia

syahrul_cb@yahoo.com

Salmy Edawati Yaacob

Pusat Kajian Syariah

Fakulti Pengajian Islam

Universiti Kebangsaan Malaysia

43600 Bangi

Selangor

Malaysia

Institut Islam Hadhari, Universiti

Kebangsaan Malaysia, 43600 UKM

Bangi

Selangor

Malaysia

salmy1001@ukm.edu.my 